\title{
Pengaruh Kejelasan Sasaran Anggaran dan Budget Emphasis Terhadap Senjangan Anggaran pada OPD Kabupaten Badung
}

\author{
Ni Putu Achintya Wibawa Putri ${ }^{1}$ \\ I G. A. M. Asri Dwija Putri \\ ${ }^{1,2}$ Fakultas Ekonomi dan Bisnis Universitas Udayana (Unud), Bali, Indonesia \\ email: achintyawibawaachintya@gmail.com / Telp: +6281 238179757
}

\begin{abstract}
ABSTRAK
Anggaran Pemerintahan daerah wajib mempertanggungjawabkan pelaksanaan Anggaran Pendapatan dan Biaya Daerah (APBD), baik dalam bentuk laporan keuangan maupun laporan kinerja jika dilihat dari alat ukur finansial berupa anggaran, masih terdapat ketidaktepatan dalam menentukan input yang pada akhirnya tidak menunjukkan efisiensi dan efektivitas anggaran. Anggaran berdampak langsung pada perilaku seseorang yang dapat menimbulkan senjangan anggaran. Penelitian ini bertujuan untuk memberikan bukti empiris mengenai pengaruh kejelasan sasaran anggaran dan budget emphasis terhadap senjangan anggaran pada OPD Kabupaten Badung. Populasi yang digunakan penelitian ini adalah 28 OPD Kabupaten Badung. Jumlah sampel yang digunakan sebanyak 110 responden, dengan metode purposive sampling. Berdasarkan hasil analisis regresi linier berganda, ditemukan bahwa kejelasan sasaran anggaran tidak berpengaruh terhadap senjangan anggaran dan budget emphasis berpengaruh positif terhadap senjangan anggaran. Hasil penelitian ini memberikan informasi bagi pihak yang terkait dalam penyusunan anggaran saat pengambilan keputusan, penentuan kebijakan dimasa akan datang, sekaligus meminimalisasi terjadinya senjangan anggaran, meningkatkan kinerja organisasi menjadi lebih transparan.
\end{abstract}

Kata kunci: Senjangan anggaran, kejelasan sasaran anggaran, dan budget emphasis.

\begin{abstract}
Local governments must account for the implementation of the Regional Revenue and Expenditure Budget (APBD), both in the form of financial statements and performance reports when viewed from financial measuring instruments in the form of budgets, there are still inaccuracies in determining inputs which ultimately do not indicate budget efficiency and effectiveness. The budget has a direct impact on a person's behavior which can lead to budgetary slack. This study aims to provide empirical evidence about the factors that influence budgetary slack in OPD of Badung Regency. This research was conducted at 28 OPD of Badung Regency. The number of samples was 110 respondents, which taken with purposive sampling technique. Based on the results of multiple linear regression analysis, it was found that budget goal clarity has no effect on budgetary slack and budget emphasis has a positive effect on budgetary slack. The results of this study provide information for the parties involved in preparing the budget when making decisions, determining policies in the future, while minimizing the occurrence of budgetary slack, be transparant to improving organizational performance.
\end{abstract}

Keywords: Budgetary slack, budget goal clarity, and budget emphasis. 


\section{PENDAHULUAN}

Anggaran menjadi fokus utama bagi aktivitas perencanaan jangka pendek yaitu satu tahun dan menjadi dasar bagi sistem pengendalian organisasi. Dalam peningkatan efisiensi dan efektifitas pelaksanaan otonomi daerah, pemerintah. Anggaran sangat berperan dalam mengomunikasikan rencana-rencana manajemen, mengalokasikan sumber daya, dan mengkoordinasikan aktivitas operasional suatu organisasi sehingga tujuan jangka panjang maupun jangka pendek dapat tercapai., terutama bagi pihak-pihak yang terlibat langsung dalam penyusunan anggaran tersebut (Siegel dan Marconi, 1989). Berbagai masalah perilaku akan muncul dalam penyusunan anggaran, misalnya terjadi pada bawahan yang ikut langsung terlibat dalam partisipasi penyusunan anggaran dan memberikan perkiraan yang bias dan tidak sesuai pada kondisi yang ada kepada atasan karena nantinya anggaran dijadikan sebagai faktor penentu penilaian kinerja, dimana bawahan memiliki informasi lebih banyak yang dapat membantu keakuratan anggaran organisasi. Perkiraan bias tersebut dilakukan dengan cara melaporkan prospek pendapatan yang lebih rendah dan prospek biaya yang lebih tinggi sehingga target anggaran dapat lebih mudah tercapai. Dengan cara ini bawahan dapat melaporkan beberapa informasi pribadi yang mungkin dapat diajukan dalam standar anggaran atau sebagai dasar dalam penyusunan RAK (Rencana Anggaran Kerja), namun jika bawahan diberi kebebasan tanpa batasan dalam menentukan target anggaran maka akan menimbulkan rendahnya motivasi bawahan dalam mencapai target yang optimal. Laporan anggaran yang bias akan mengurangi keefektifan anggaran di dalam perencanaan dan pengawasan 
organisasi (Waller, 1988). Menurut Anthony dan Govindarajan (2007) menyatakan bahwa terjadinya senjangan anggaran (budgetary slack) karena adanya perbedaan antara anggaran yang dilaporkan dengan anggaran yang sesuai dengan estimasi terbaik bagi organisasi, pelaporan dari jumlah anggaran tersebut dengan sengaja dilaporkan melebihi sumber daya yang dimiliki organisasi.

Pemerintahan daerah dalam hal ini wajib mempertanggungjawabkan pelaksanaan Anggaran Pendapatan dan Biaya Daerah, baik dalam bentuk laporan keuangan maupun laporan kinerja jika dilihat dari alat ukur finansial berupa anggaran, masih terdapat ketidaktepatan dalam menentukan input, yang pada akhirnya tidak menunjukkan efisiensi dan efektivitas anggaran (Yeyen, 2013). Terjadinya senjangan anggaran dapat dilihat dalam Laporan Realisasi Anggaran Pendapatan dan Belanja Daerah (RAPBD) Kabupaten Badung Tahun Anggaran 2015-2017. Dapat dilihat dalam ringkasan laporan tersebut, masih ada selisih lebih dan selisih kurang antara anggaran yang ditetapkan dengan realisasi anggaran. Pastinya berbagai faktor pemicu bawahan menciptakan senjangan tersebut seperti faktor risiko tinggi dan adanya ketidakpastian lingkungan yang dimana terdapat pengeluaran dana anggaran yang tidak sesuai dengan kondisi yang diprediksi atau penggunaan dana anggaran untuk keperluan yang sangat urgent. (Dunk, 1998). Disamping itu tidak dipungkiri adanya faktor kesengajaan, keadaan tersebut mengindikasikan bahwa kemungkinan anggaran pendapatan sengaja dibuat kecil dari estimasi yang sebenarnya agar target anggaran lebih mudah dicapai sehingga kinerja pemerintah terlihat baik (Negara dan Wirajaya, 2018). 
Tabel 1.

Laporan Realisasi Anggaran Pendapatan dan Belanja Daerah Kabupaten Badung Tahun Anggaran 2015-2017

\begin{tabular}{llll}
\hline Tahun & $\begin{array}{l}\text { Anggaran Pendapatan } \\
\text { (ribuan rupiah) }\end{array}$ & $\begin{array}{l}\text { Realisasi Pendapatan } \\
\text { (ribuan rupiah) }\end{array}$ & $\begin{array}{l}\text { Selisih } \\
\text { (ribuan rupiah) }\end{array}$ \\
\hline 2015 & 3.627 .734 .540 & 3.735 .129 .565 & $(107.395 .025)$ \\
2016 & 3.948 .077 .205 & 4.328 .245 .675 & $(380.168 .470)$ \\
2017 & 5.096 .064 .815 & 4.937 .606 .911 & 158.457 .904 \\
Tahun & $\begin{array}{l}\text { Anggaran Belanja } \\
\text { (ribuan rupiah) }\end{array}$ & $\begin{array}{l}\text { Realisasi Belanja } \\
\text { (ribuan rupiah) }\end{array}$ & $\begin{array}{l}\text { Selisih } \\
\text { (ribuan rupiah) }\end{array}$ \\
2015 & 3.339 .512 .375 & 2.749 .811 .018 & 589.701 .357 \\
2016 & 3.849 .200 .151 & 3.391 .181 .767 & 458.018 .384 \\
2017 & 5.214 .266 .110 & 4.461 .016 .113 & 753.249 .997 \\
\hline
\end{tabular}

Sumber: http://Badungkab.go.id, 2019

Pada laporan RAPBD tersebut bahwa kinerja Organisasi Perangkat daerah

(OPD) Kabupaten Badung kurang optimal, terbukti dalam penetapan anggaran belanja langsung dari tahun 2015-2017 masih adanya selisih antara anggaran yang ditetapkan dengan anggaran yang terealisasi, laporan realisasi pendapatan daerah tahun 2015 sampai dengan 2017 di buat lebih tinggi dari laporan anggaran pendapatan daerah serta laporan realisasi belanja daerah pada tahun 2015 sampai dengan 2017 dibuat lebih rendah dari laporan anggaran belanja daerah sehingga dapat disimpulkan masih adanya senjangan anggaran. Kecenderungan untuk melakukan senjangan anggaran akan lebih rendah apabila terdapat kejelasan dari sasaran anggaran yang digunakan dengan kata lain harus transparan dari perencanaan hingga pelaporannya serta maminimalisasi tekanan yang berlebih dari atasan kepada bawahan selaku yang bertanggung jawab terhadap pelaksanaan anggaran.

Penelitian terhadap senjangan anggaran telah banyak diteliti, misalnya Dunk (1993) melakukan penelitian dengan menganalisis pengaruh interaksi anggaran, informasi asimetri diantara atasan dan bawahan, dan budget emphasis 
yang digunakan atasan dalam menilai kinerja bawahannya terhadap budgetary slack. Putri (2016) meneliti tentang pengaruh kejelasan sasaran anggaran, karakter personal, dan information asymmetry pada senjangan anggaran. Dapat disimpulkan dari kedua penelitian tersebut yang dihubungkan dengan penelitian ini bahwa variabel kejelasan sasaran anggaran berpengaruh negatif terhadap senjangan anggaran, di mana semakin jelasnya sasaran anggaran maka kecenderungan untuk terjadinya senjangan anggaran semakin rendah serta variabel budget emphasis berpengaruh positif terhadap senjangan anggaran artinya meningkatnya senjangan anggaran apabila meningkatnya pengaruh budget emphasis. Namun berbeda dengan penelitian Biantara dan Putri (2014) mengenai pengaruh kejelasan sasaran anggaran, etika, dan kepercayaan diri pada senjangan anggaran, hasilnya menunjukkan bahwa variabel kejelasan sasaran anggaran berpengaruh positif artinya sasaran anggaran yang jelas mengakibatkan pejabat (atasan) dapat membandingkan kinerja yang telah dilakukan dengan sasaran anggaran tersebut serta dengan etika dan kepercayaan diri yang tinggi akan menurunkan senjangan anggaran.

Penelitian yang dilakukan oleh beberapa peneliti masih menunjukkan adanya ketidakkonsistenan, selain itu topik mengenai senjangan anggaran masih sangat penting untuk diteliti karena masih sering terjadi senjangan anggaran baik dalam organisasi sektor publik maupun swasta sehingga peneliti ingin mengetahui pengaruh kejelasan sasaran anggaran dan budget emphasis terhadap senjangan anggaran pada OPD Kabupaten Badung. 
Penelitian ini diharapkan dapat memberikan manfaat baik dari segi teoritis maupun praktis. Manfaat teoritis di mana penelitian ini diharapkan dapat memberikan bukti empiris yang menjelaskan pengaruh kejelasan sasaran anggaran dan budget emphasis terhadap senjangan anggaran pada OPD Kabupaten Badung. Kegunaan praktis yaitu penelitian diharapkan mampu memberikan informasi yang dapat bermanfaat serta dapat digunakan untuk bahan pertimbangan bagi organisasi di dalam menempatkan kebijakan di masa yang akan datang terkait dengan pengaruh kejelasan sasaran anggaran dan budget emphasis terhadap senjangan anggaran pada OPD Kabupaten Badung.

Jensen dan Meckling (1976) mendefinisikan teori keagenan sebagai hubungan kontraktual antara dua pihak, yaitu pemilik perusahaan yang memberikan wewenang sebagai pihak principal dengan pengelola perusahaan atau manajemen yang melaksanakan wewenang tersebut sebagai pihak agent. Hal yang sering terjadi, dimana pihak yang melaksanakan melaksanakan wewenang cenderung lebih memprioritaskan kepentingan pribadinya dibandingkan dengan kepentingan perusahaan dan pemiliknya sehingga timbullah kesenjangan anggaran agar lebih mudah bagi agent untuk memenuhi target anggaran sesuai apa yang diinginkan pemilik perusahaan agar nantinya kinerja mereka terlihat baik dan dinilai berhasil memenuhi target. Adanya penilaian kinerja agent bedasarkan tingkat pencapaian target anggaran juga dapat menyebabkan pihak agen melakukan kesenjangan anggaran dimana mereka menginginkan imbalan atau reward ketika mereka telah mencapai target yang ditetapkan (Novitasari, 2015). 
Anggaran khusunya pada organisasi sektor publik berisi kegiatan yang digambarkan dalam bentuk rencana perolehan pendapatan dan belanja dalam satuan moneter, setiap anggaran memberikan informasi mengenai jumlah dan caranya memperoleh dana untuk merealisasikan rencana tersebut dan menetapkan biaya atas rencana-rencana yang dibuat (Mardiasmo, 2018:81). Dalam penyusunan anggaran melalui empat siklus yang meliputi empat tahap, yaitu tahap persiapan, ratifikasi, evaluasi pelaporan serta yang terakhir evaluasi anggaran. Senjangan anggaran adalah selisih antara jumlah yang dianggarkan dengan jumlah realisasi dalam melaksanakan kegiatan tertentu. Senjangan atau selisih pada anggaran dilakukan dengan membuat perencanaan biaya lebih tinggi dan pendapatan lebih rendah (Hobson et al., 2011). Schiff dan Lewin (1970) menyatakan bahwa bawahan melakukan senjangan anggaran karena pengaruh dari keinginan pribadi dan ingin memperoleh reward atas keberhasilan target anggaran yang dicapai. Hal ini akan memudahkan dalam mencapai target anggaran, terutama jika prestasi kinerja bawahan ditentukan berdasarkan tingkat sejauh mana keberhasilan dalam pencapaian anggaran tersebut (Douglas dan Wier, 2005).

Sistem penganggaran memiliki beberapa karakteristik yang salah satunya dipengaruhi oleh jelas atau tidaknya sasaran dari anggaran tersebut. (Kenis, 1979). Pitasari dkk, (2014) menyatakan bahwa kejelasan sasaran anggaran adalah sejauh mana anggaran diterapkan secara jelas, spesifik, transparan, dan mudah dimengerti dengan tujuan agar anggaran tersebut dapat dengan mudah dipertanggungjawabkan penggunaannya oleh orang yang bertanggungjawab 
terhadap keberhasilan ataupun kegagalan dari pelaksanaan tugas yang telah dilaksanakan dalam rangka mencapai tujuan dan sasaran yang telah ditetapkan saat proses perencanaan anggaran. Adanya sasaran anggaran yang jelas maka akan mempermudah dalam mempertanggungjawabkan penggunaan anggaran kepada atasan sehingga dapat meminimalisasi terjadinya senjangan anggaran. Berdasarkan hal tersebut, maka hipotesis pertama yang dapat ditarik dalam penelitian ini sebagai berikut:

$\mathrm{H}_{1}$ : Kejelasan sasaran anggaran berpengaruh negatif terhadap senjangan anggaran pada OPD Kabupaten Badung.

Budget emphasis merupakan pressure atau tekanan terhadap pelaksanaan anggaran dari atasan kepada bawahan untuk melaksanakan anggaran yang telah dibuat sesuai dengan rancangan anggaran yang telah ditetapkan, bawahan akan dikenakan sanksi serta tidak mendapatkan tambahan bonus atau imbalan apabila dalam realisasi anggaran target tidak tercapai namun akan diberikan kompensasi jika anggaran sesuai target. Hal ini, bermanfaat sebagai alat pengukuran untuk menilai kinerja anggaran yang ditetapkan, di mana anggaran hanya digunakan sebagai panduan untuk penilaian kinerja sehingga mendorong bawahan untuk menciptakan senjangan anggaran (Aprila dan Hidayani, 2012). Kung et al., (2013) menyatakan bahwa budget emphasis dapat membantu untuk mencapai tujuan anggaran, namun jika terlalu ketat menyebabkan perilaku yang menyimpang pada bawahan. Berdasarkan hal itu, maka hipotesis ketiga yang dapat ditarik dalam penelitian ini sebagai berikut:

$\mathrm{H}_{2}$ : Budget emphasis berpengaruh positif terhadap senjangan anggaran pada OPD Kabupaten Badung. 


\section{METODE PENELITIAN}

Penelitian ini menggunakan pendekatan kuantitatif berbentuk asosiatif. Penelitian asosiatif merupakan penelitian yang bertujuan untuk mengetahui hubungan antara dua variabel atau lebih (Sugiyono (2017:23). Lokasi penelitian dilakukan pada 28 Organisasi Perangkat Daerah (OPD) Kabupaten Badung. Objek penelitian ini adalah pengaruh kejelasan sasaran anggaran dan budget emphasis terhadap senjangan anggaran pada OPD Kabupaten Badung.

Kejelasan sasaran anggaran diukur dengan menggunakan tujuh pernyataan yang diadopsi dari penelitian yang telah dilakukan oleh Putri (2016) dengan menggunakan skala likert 1 sampai 5. Semakin tinggi nilai yang diperoleh maka menunjukkan semakin tingginya kejelasan sasaran anggaran. Budget emphasis diukur dengan menggunakan kuesioner dengan lima pernyataan yang diadopsi dari penelitian Dunk (1993) yang menunjukkan semakin tinggi nilai jawaban responden maka semakin tinggi adanya budget emphasis. Populasi yang digunakan dalam penelitian ini adalah pejabat yang berwenang dalam penyusunan anggaran pada masing-masing OPD Kabupaten Badung. Sampel yang digunakan sebanyak 110 responden dengan menggunakan teknik purposive sampling. Adapun kriteria penentuan sampel yang digunakan individu yang menduduki jabatan sebagai sekretaris, kepala dinas/kepala badan/camat, sub bagian keuangan, dan sub bagian perencanaan yang terlibat di dalam penyusunan anggaran. Metode pengumpulan data yang digunakan yaitu metode survei dengan kuesioner, kuesioner disebarkan langsung kepada responden berupa pernyataan mengenai 
faktor-faktor yang mempengaruhi senjangan anggaran yang diukur dengan skala likert satu sampai lima.

Teknik analisis data diawali dengan uji instrumen penelitian yaitu uji validitas serta uji reliabilitas. Instrumen penelitian dikatakan valid apabila nilai pearson correlation lebih besar dari 0,3 (Sugiyono 2017:512). Uji reliabilitas adalah pengujian instrumen yang dilakukan untuk mengukur konsistensi serta stabilitas dari kuesioner. Kuesioner dikatakan reliabel apabila nilai cronbach alpha yang diperoleh lebih besar dari 0,7 (Ghozali, 2016:58).

Analisis statistik deskriptif digunakan untuk menjelaskan deskripsi dari seluruh variabel yang akan dimasukkan dalam model penelitian yang dilihat dari nilai rata-rata (mean), standar deviasi, nilai minimum, nilai maksimum. Statistik deskriptif diukur dengan menggunakan program SPSS. Uji asumsi klasik adalah pengujian instrumen untuk mengetahui hubungan variabel bebas dan variabel terikat agar terbebas dari gejala asumsi klasik yang meliputi uji normalitas, uji multikolinearitas, dan uji heteroskedastisitas. Untuk menguji normal atau tidaknya sebuah model dapat dilakukan uji statistik non-parametrik kolmogorov-sminarnov. Nilai koefisien Asymp.sig (2-tailed) lebih besar dari 0,05, maka dapat dikatakan bahwa data terdistribusi secara normal. Pengujian yang dilakukan untuk menguji adanya korelasi antar variabel bebas disebut dengan uji multikolinearitas di mana nilai variance inflation factor (VIF) kurang dari 10 atau nilai tolerance lebih dari 0,1 menunjukkan variabel terbebas dari gejala multikolinearitas. Pada uji heteroskedastisitas dilakukan dengan uji glejser untuk mendeteksi adanya gejala 
heteroskedastisitas. Model regresi terbebas dari gejala heteroskedastisitas apabila nilai signifikansi yang diperoleh lebih besar dari 0,05 .

Pengaruh kejelasan sasaran anggaran dan budget emphasis terhadap senjangan anggaran dapat diketahui dengan melakukan analisis regresi linier berganda yang akan diuji dengan tingkat signifikansi. Model analisis regresi linear berganda dalam penelitian ini dapat dinyatakan dalam persamaan regresi sebagai berikut:

$$
\mathrm{Y}=\alpha+\beta_{1} \mathrm{X}_{1}+\beta_{2} \mathrm{X}_{2}+\mathrm{e}
$$

Keterangan:

$$
\begin{array}{ll}
\mathrm{Y} & =\text { Senjangan Anggaran } \\
\alpha & =\text { Konstanta } \\
\beta_{1}-\beta_{2} & =\text { Koefisien Regresi } \\
\mathrm{X}_{1} & =\text { Kejelasan Sasaran Anggaran } \\
\mathrm{X}_{2} & =\text { Budget Emphasis } \\
\mathrm{e} & =\text { Kesalahan/standar error }
\end{array}
$$

Goodness of Fit dari analisis regresi linier berganda dapat diamati dengan menggunakan nilai koefisien determinasi, uji kelayakan model, dan uji hipotesis. Nilai koefisien determinasi dilihat dari nilai Adjusted $\mathrm{R}^{2}$, apabila nilainya tinggi mendekati atau sama dengan 1 artinya variabel bebas mampu menjelaskan variasi variabel terikat. Uji kelayakan model (uji F) yaitu pengujian untuk menguji pengaruh variabel bebas terhadap variabel terikat. Hasil uji F yang signifikan adalah apabila nilai Sig. $F \leq 0,05$. Pengujian hipotesis (uji t) dilakukan untuk menguji pengaruh dari masing-masing variabel independen terhadap variabel dependen (Ghozali, 2016:99). Apabila terdapat nilai p-value lebih kecil 0,05 maka hipotesis penelitian diterima, sebaliknya apabila nilai p-value lebih besar dari 0,05 maka hipotesis penelitian ditolak. 


\section{HASIL DAN PEMBAHASAN}

Kuesioner yang tersebar sebanyak 112 kuesioner. Kuesioner kembali dan dapat digunakan dalam kriteria sampel sebanyak 110 kuesioner. Karakteristik responden dapat dilihat pada Tabel 2.

Tabel 2.

Karakteristik Responden

\begin{tabular}{|c|c|c|c|}
\hline No & Kriteria & Jumlah Responden & $\begin{array}{c}\text { Presentase } \\
(\%)\end{array}$ \\
\hline \multirow{4}{*}{1} & Jenis Kelamin & & \\
\hline & a. Laki-laki & 49 orang & $44 \%$ \\
\hline & b. Perempuan & 61 orang & $56 \%$ \\
\hline & TOTAL & 110 orang & $100 \%$ \\
\hline \multirow[t]{6}{*}{2} & Usia & & \\
\hline & a. 20-30 tahun & 3 orang & $3 \%$ \\
\hline & b. $31-40$ tahun & 22 orang & $20 \%$ \\
\hline & c. 41-50 tahun & 45 orang & $40 \%$ \\
\hline & d. $>51$ tahun & 40 orang & $37 \%$ \\
\hline & TOTAL & 110 orang & $100 \%$ \\
\hline \multirow[t]{6}{*}{3} & Jabatan & & \\
\hline & a. Kepala dinas/kepala badan/camat & 28 orang & $25 \%$ \\
\hline & b. Sekretaris & 29 orang & $26 \%$ \\
\hline & c. Sub Bagian Keuangan & 27 orang & $25 \%$ \\
\hline & d. Sub Bagian Perencanaan & 26 orang & $24 \%$ \\
\hline & TOTAL & 110 orang & $100 \%$ \\
\hline \multirow[t]{7}{*}{4} & Pendidikan Terakhir & & \\
\hline & a. SMA & 9 orang & $8 \%$ \\
\hline & b. D3 & - & - \\
\hline & c. $\mathrm{S} 1$ & 69 orang & $63 \%$ \\
\hline & d. $\mathrm{S} 2$ & 32 orang & $29 \%$ \\
\hline & e. $\mathrm{S} 3$ & - & - \\
\hline & TOTAL & 110 orang & $100 \%$ \\
\hline \multirow[t]{6}{*}{5} & Lama Bekerja & & \\
\hline & a. $<1$ tahun & - & - \\
\hline & b. $1-5$ tahun & 52 orang & $47 \%$ \\
\hline & c. 6-10 tahun & 15 orang & $14 \%$ \\
\hline & d. $>10$ tahun & 43 orang & $39 \%$ \\
\hline & TOTAL & 110 orang & $100 \%$ \\
\hline
\end{tabular}

Sumber: Data diolah, 2018

Berdasarkan Tabel 2 dapat diketahui bahwa jumlah responden laki-laki adalah sebanyak 49 orang (44\%) dan jumlah responden perempuan sebanyak 61 orang (56\%). Hal ini menunjukkan bahwa yang menduduki jabatan sebagai sekretaris, kepala dinas/kepala badan/camat, bagian keuangan, dan bagian perencanaan pada OPD Kabupaten Badung lebih banyak berjenis kelamin perempuan. Proporsi 
responden yang berusian antara 20 sampai 30 tahun sebanyak 3 orang (3\%), yang berusia 31 sampai 40 tahun sebanyak 20 orang (20\%), yang berusia 41 sampai 50 tahun sebanyak 45 orang (40\%), dan yang berusia diatas 51 tahun sebanyak 40 orang (37\%). Responden terbanyak berada pada usia 41 sampai 50 tahun sehingga diharapkan responden telah memiliki kematangan dalam berpikir serta dapat memberikan jawaban yang lebih objektif dengan pengalaman yang didapatkan.

Pada Tabel 2 dapat dilihat pula bahwa responden yang menduduki jabatan sebagai kepala dinas/kepala badan/camat adalah sebanyak 28 orang (25\%), sekretaris sebanyak 29 orang (26\%), sub bagian keuangan sebanyak 27 orang (25\%), dan sub bagian perencanaan sebanyak 26 orang (24\%). Pendidikan terakhir yang dimiliki oleh responden didominasi oleh tingkat pendidikan S1 yaitu sebanyak 69 orang (63\%), 32 responden (30\%) memiliki pendidikan terakhir S2, 9 responden $(8 \%)$ memiliki pendidikan terakhir SMA, dan tidak ada responden yang memiliki pendidikan terakhir D3 dan S3.

Kriteria lama bekerja dapat menjelaskan seberapa lama responden telah menduduki jabatan dan telah mengabdikan dirinya, serta dapat pula menunjukkan pengalaman yang telah dimiliki di dalam penyusunan anggaran. Tidak ada responden yang menduduki jabatannya selama kurang dari 1 tahun, sementara responden yang telah menduduki jabatannya selama 1 sampai 5 tahun adalah sebanyak 52 orang (47\%), responden yang telah menduduki jabatannya selama 6 sampai 10 tahun yaitu sebanyak 15 orang (14\%), dan sebanyak 43 orang (39\%) telah menduduki jabatan selama lebih dari 10 tahun. Hal ini menunjukkan bahwa mayoritas responden telah menduduki jabatannya selama 1 sampai 5 tahun. 
Statistik deskriptif disajikan untuk memberikan informasi mengenai karakteristik variabel-variabel penelitian, antara lain nilai minimum, maksimum, rata-rata, dan simpangan baku.

Tabel 3.

Hasil Statistik Deskriptif

\begin{tabular}{clccccc}
\hline No & \multicolumn{1}{c}{ Variabel } & N & Min. & Max. & Mean & $\begin{array}{c}\text { Std. } \\
\text { Deviasi }\end{array}$ \\
\hline 1 & Senjangan Anggaran (Y) & 110 & 14,00 & 30,00 & 25,3273 & 3,40563 \\
2 & Kejelasan Sasaran Anggaran (X1) & 110 & 17,00 & 30,00 & 24,8000 & 2,48223 \\
3 & Budget Emphasis (X2) & 110 & 11,00 & 25,00 & 20,5545 & 2,70435 \\
\hline Sumber: Data diolah, 2018
\end{tabular}

Sumber: Data diolah, 2018

Berdasarkan Tabel 3 dapat dilihat bahwa jumlah pengamatan $(\mathrm{N})$ dari penelitian ini adalah sebanyak 110. Nilai terendah dari data ditunjukkan oleh skor min. dalam tabel, sedangkan nilai tertinggi dari data ditunjukkan oleh skor max. Mean digunakan untuk mengukur nilai rata-rata dari data, dan standard deviation menunjukkan simpangan baku.

Variabel senjangan anggaran memiliki nilai minimum sebesar 14,00 dan nilai maksimum sebesar 30,00 dengan nilai rata-rata sebesar 25,3273 yang menunjukkan bahwa respon responden dalam menjawab pernyataan pada kuesioner cenderung merasa setuju pada masing-masing item pernyataan artinya senjangan anggaran cenderung tinggi. Standar deviasi pada variabel senjangan anggaran adalah sebesar 3,40563. Variabel kejelasan sasaran anggaran memiliki nilai minimum sebesar 17,00 dan nilai maksimum sebesar 30,00 dengan nilai ratarata sebesar 24,8000 yang menunjukkan bahwa respon responden dalam menjawab pernyataan pada kuesioner cenderung merasa setuju pada masingmasing item pernyataan artinya kejelasan sasaran anggaran cenderung tinggi. Standar deviasi pada variabel kejelasan sasaran anggaran adalah sebesar 2,48223. 
Hal ini menunjukkan bahwa standar penyimpangan data terhadap nilai rataratanya adalah 2,48223. Variabel budget emphasis memiliki nilai minimum sebesar 11,00 dan nilai maksimum sebesar 25,00 dengan nilai rata-rata sebesar 20,5545 yang menunjukkan bahwa respon responden dalam menjawab pernyataan pada kuesioner cenderung merasa setuju pada masing-masing item pernyataan artinya budget emphasis cenderung tinggi. Standar deviasi pada variabel budget emphasis adalah sebesar 2,70435. Hal ini menunjukkan bahwa standar penyimpangan data terhadap nilai rata-ratanya adalah 2,70435 .

Tabel 4 dan Tabel 5 adalah tabel yang menyajikan informasi mengenai hasil dari uji instrumen yang telah dilakukan pada penelitian ini. Tabel 4 menyajikan hasil dari uji validitas, sedangkan Tabel 5 menyajikan hasil dari uji reliabilitas.

Tabel 4.

Hasil Uji Validitas

\begin{tabular}{|c|c|c|c|c|}
\hline No & Variabel & $\begin{array}{c}\text { Kode } \\
\text { Instrumen }\end{array}$ & $\begin{array}{c}\text { Nilai Pearson } \\
\text { Correlation }\end{array}$ & Keterangan \\
\hline 1 & Senjangan Anggaran (Y) & Y1.1 & 0,554 & Valid \\
\hline & & $\begin{array}{l}\text { Y1.2 } \\
\text { Y1.3 } \\
\text { Y1.4 } \\
\text { Y1.5 } \\
\text { Y1.6 }\end{array}$ & $\begin{array}{l}0,710 \\
0,824 \\
0,830 \\
0,795 \\
0,834\end{array}$ & $\begin{array}{l}\text { Valid } \\
\text { Valid } \\
\text { Valid } \\
\text { Valid } \\
\text { Valid }\end{array}$ \\
\hline 2 & $\begin{array}{l}\text { Kejelasan Sasaran Anggaran } \\
\text { (X1) }\end{array}$ & $\mathrm{X} 1.1$ & 0,487 & Valid \\
\hline & & $\begin{array}{l}\mathrm{X} 1.2 \\
\mathrm{X} 1.3 \\
\mathrm{X} 1.4 \\
\mathrm{X} 1.5 \\
\mathrm{X} 1.6 \\
\mathrm{X} 1.7\end{array}$ & $\begin{array}{l}0,567 \\
0,647 \\
0,650 \\
0,588 \\
0,560 \\
0,426\end{array}$ & $\begin{array}{l}\text { Valid } \\
\text { Valid } \\
\text { Valid } \\
\text { Valid } \\
\text { Valid } \\
\text { Valid }\end{array}$ \\
\hline 3 & Budget Emphasis (X2) & $\begin{array}{l}\mathrm{X} 2.1 \\
\mathrm{X} 2.2 \\
\mathrm{X} 2.3 \\
\mathrm{X} 2.4 \\
\mathrm{X} 2.5\end{array}$ & $\begin{array}{l}0,728 \\
0,728 \\
0,748 \\
0,777 \\
0,649 \\
0,806\end{array}$ & $\begin{array}{l}\text { Valid } \\
\text { Valid } \\
\text { Valid } \\
\text { Valid } \\
\text { Valid }\end{array}$ \\
\hline
\end{tabular}

Sumber: Data diolah, 2018 
Tabel 4 menunjukkan bahwa seluruh variabel penelitian adalah valid karena nilai pearson correlation yang diperoleh lebih besar dari 0,3 .

Tabel 5.

Hasil Uji Reliabilitas

\begin{tabular}{clcc}
\hline No & \multicolumn{1}{c}{ Variabel } & Cronbach's Alpha & Kerterangan \\
\hline 1 & Senjangan Anggaran (Y) & 0,791 & Reliabel \\
2 & Kejelasan Sasaran Anggaran (X1) & 0,751 & Reliabel \\
3 & Budget Emphasis (X2) & 0,786 & Reliabel \\
\hline \multicolumn{2}{l}{ Sumber: Data diolah 2018}
\end{tabular}

Sumber: Data diolah, 2018

Tabel 5 menunjukkan seluruh variabel penelitian reliabel karena nilai cronbach's alpha yang diperoleh lebih besar dari 0,70. Selanjutnya dilakukan uji asumsi klasik yang disajikan pada Tabel 6,7, dan 8, meliputi: uji normalitas, uji multikolienaritas dan uji heteroskedastisitas.

Tabel 6.

Hasil Uji Normalitas

\begin{tabular}{cc}
\hline Kolmogorov-Smirnov & Unstandardized Residual \\
\hline $\mathrm{N}$ & 110 \\
Asymp. Sig. (2-tailed) & 0,664 \\
\hline
\end{tabular}
Sumber: Data diolah, 2018

Uji normalitas menggunakan uji non-parametrik satu sampel KolmogorovSmirnov. Nilai Asymp. Sig (2-tailed) sebesar 0,664. Tabel 6 menunjukkan Asymp. Sig (p-value) 0,664 lebih besar daripada $\alpha(0,05)$, maka dapat diinterpretasikan bahwa residual dari model telah berdistribusi normal.

Tabel 7. Hasil Uji Multikolinearitas

\begin{tabular}{cccc}
\hline No & \multicolumn{1}{c}{ Variabel } & Tolerance & VIF \\
\hline 1 & Kejelasan Sasaran Anggaran (X1) & 0,591 & 1,693 \\
2 & Budget Emphasis (X2) & 0,591 & 1,693 \\
\hline \multicolumn{2}{l}{ Sumber: Data diolah, 2018 }
\end{tabular}

Tabel 7 menunjukkan bahwa nilai tolerance seluruh variabel bebas lebih besar dari 0,1, dan nilai VIF yang diperoleh lebih kecil dari 10, sehingga dapat disimpulkan bahwa tidak ada gejala multikolinearitas antar variabel bebas. 
Tabel 8.

Hasil Uji Heteroskedastisitas

\begin{tabular}{llcl}
\hline \multicolumn{1}{c}{ Model } & Sig. & Keterangan \\
\hline 1 & (Constant) & & \\
& Kejelasan Sasaran Anggaran (X1) & 0,694 & Bebas Heteroskedastisitas \\
& Budget Emphasis (X2) & 0,728 & Bebas Heteroskedastisitas \\
\hline
\end{tabular}

Sumber: Data diolah, 2018

Uji heteroskedastisitas bertujuan untuk menguji apakah dalam model regresi terjadi ketidaksamaan variance dari residual satu pengamatan ke pengamatan yang lain. Tabel 8 menunjukkan bahwa nilai signifikansi $>$ dari 0,05 . Dapat disimpulkan bahwa model penelitian yang dirumuskan bebas dari gejala heteroskedastisitas.

Tabel 9.

Hasil Analisis Regresi Linear Berganda

\begin{tabular}{|c|c|c|c|c|c|c|}
\hline \multirow{2}{*}{\multicolumn{2}{|c|}{ Model }} & \multicolumn{2}{|c|}{$\begin{array}{c}\text { Unstandardized } \\
\text { Coefficients }\end{array}$} & \multirow{2}{*}{$\begin{array}{c}\text { Unstandardized } \\
\text { Coefficients } \\
\text { Beta }\end{array}$} & \multirow[t]{2}{*}{$\mathbf{t}$} & \multirow[t]{2}{*}{ Sig. } \\
\hline & & B & Std. Error & & & \\
\hline \multirow[t]{7}{*}{1} & (Constant) & 5,172 & & & & \\
\hline & $\mathrm{X} 1$ & 0,198 & 0,125 & 0,114 & 1,584 & 0,116 \\
\hline & $\mathrm{X} 2$ & 0,742 & 0,115 & 0,589 & 6,473 & 0,000 \\
\hline & $\mathrm{R}$ & & 0,690 & & & \\
\hline & Adjusted $\mathrm{R}^{2}$ & & 0,477 & & & \\
\hline & $\mathrm{F}_{\text {hitung }}$ & & 48,708 & & & \\
\hline & Sig. F & & 0,000 & & & \\
\hline
\end{tabular}

Berdasarkan hasil yang diperoleh dari analisis regresi linear berganda pada Tabel 9 dapat di buat persamaan yaitu:

$$
\mathrm{Y}=5,172+0,198 \mathrm{X} 1+0,742 \mathrm{X} 2+\mathrm{e} \ldots \ldots(2)
$$

Nilai konstanta sebesar 5,172 menunjukkan bahwa bila nilai kejelasan sasaran anggaran (X1) dan budget emphasis (X2) sama dengan nol, maka cenderung terdapat senjangan anggaran (Y). Nilai koefisien $\beta 1=0,198$ menunjukkan kejelasan sasaran anggaran (X1) bernilai positif, hal ini berarti kejelasan sasaran anggaran mempunyai pengaruh positif terhadap senjangan anggaran, bila kejelasan sasaran anggaran meningkat satu satuan akan cenderung 
meningkatkan senjangan anggaran dengan asumsi variabel lainnya sama dengan nol. Nilai koefisien $\beta 2=0,742$ menunjukkan budget emphasis (X2) bernilai positif, hal ini berarti budget empahsis mempunyai pengaruh positif terhadap senjangan anggaran, bila budget empahsis meningkat satu satuan akan cenderung meningkatnya senjangan anggaran dengan asumsi variabel lainnya sama dengan nol.

Koefisien determinasi dapat dilihat dari nilai Adjusted R Square sebesar 0,467. Hal ini menunjukkan bahwa $46,7 \%$ variasi senjangan anggaran dapat dijelaskan oleh variabel kejelasan sasaran anggaran dan budget emphasis sedangkan sisanya sebesar 53,3\% dijelaskan oleh variabel lain dari luar model penelitian. Berdasarkan Tabel 9 menunjukkan bahwa nilai F signifikansi yaitu 0,000 lebih kecil dari 0,05. Hal ini menunjukkan variabel kejelasan sasaran anggaran dan budget emphasis secara bersama-sama (simultan) berpengaruh pada senjangan anggaran dapat diketahui dengan melakukan uji $\mathrm{F}$.

Berdasarkan hasil perhitungan yang ditunjukkan pada Tabel 9 bahwa variabel kejelasan sasaran anggaran berpengaruh positif terhadap senjangan anggaran pada OPD Kabupaten Badung. Hal ini ditunjukkan dengan nilai Beta sebesar 0,144 dan nilai signifikansi sebesar 0,116 yang lebih kecil dari tingkat signifikasi yang ditetapkan $(\alpha=0,05)$ sehingga hipotesis pertama $\left(\mathrm{H}_{1}\right)$ ditolak. Hasil penelitian menunjukkan semakin tinggi ataupun semakin rendah kejelasan sasaran anggaran dalam penyusunan anggaran tidak berpengaruh terhadap senjangan anggaran yang terjadi pada OPD Kabupaten Badung. 
Kejelasan sasaran anggaran sangat diperlukan dalam proses penyusunan anggaran, realisasi anggaran serta pertanggungjawaban anggaran tersebut. Adanya sasaran anggaran yang jelas akan memudahkan dalam mempertanggungjawabkan keberhasilan atau kegagalan pelaksanaan tugas organisasi dalam rangka untuk mencapai tujuan-tujuan maupun sasaran-sasaran yang telah ditetapkan sebelumnya. Agar kejelasan sasaran anggaran tercapai dengan mudah maka manajemen akan mengandalkan beberapa cara, salah satunya dengan melakukan senjangan anggaran. Selain itu, anggaran pada anggaran sektor publik seringkali bersifat kaku dan susah disesuikan dengan keadaan yang sesungguhnya, para perancang anggaran dan pihak yang menggunakan dana anggaran harus mengikuti aturan mulai dari perencanaan, pengelolaan, realisasi, dan pelaporannya harus jelas sesuai dengan pedoman rencana kerja dan anggaran OPD Kabupaten Badung sehingga tidak ada penyelewengan dana yang dianggarkan dan tidak terjadi senjangan anggaran, baik itu senjangan lebih maupun senjangan kurang. Penelitian ini sejalan dengan hasil penelitian Hariyanti dan Kuntaryanto (2014) yang menunjukkan bahwa kejelasan sasaran anggaran tidak memoderasi pengaruh partisipasi anggaran terhadap senjangan anggaran dan penelitian dari Karidwan dan Mahmud (2014) menunjukan bahwa secara parsial variabel kejelasan sasaran anggaran tidak memiliki pengaruh terhadap senjangan anggaran Satuan Kerja Perangkat Daerah (SKPD) Kabupaten Sukoharjo. Hasil penelitian ini tidak sesuai dengan hipotesis yang diajukan sebelumnya dan tidak sejalan dengan penelitian sebelumnya yaitu Erina dan Suartana (2016); Wiguna dan Wirasedana (2016) yang menyatakan bahwa kejelasan sasaran anggaran berpengaruh negatif dan 
signifikan terhadap senjangan anggaran serta hasil penelitian Yanti dan Sari (2016) serta Biantara dan Putri (2014) yang menemukan bahwa variabel kejelasan sasaran anggaran berpengaruh positif pada senjangan anggaran. Faktor lain yang memungkinkan terjadinya ketidakkonsistenan dengan hasil penelitian sebelumnya, dimana responden kurang mengerti dengan maksud setiap pertanyaan pada kuesioner penelitian ini sehingga saat menjawab setiap pertanyaan tidak sungguh-sungguh dengan keadaan yang sebenarnya, atau kemungkinan yang kedua kurangnya generalisasi sampel yang dipilih peneliti dan kurangnya kontribusi peneliti untuk menjelaskan maksud setiap item pertanyaan.

Berdasarkan hasil perhitungan yang ditunjukkan pada Tabel 4.9 bahwa variabel budget emphasis berpengaruh positif terhadap senjangan anggaran pada OPD Kabupaten Badung. Hal ini ditunjukkan dengan nilai Beta sebesar 0,589 dan nilai signifikansi sebesar 0,000 yang lebih kecil dari tingkat signifikasi yang ditetapkan $(\alpha=0,05)$ sehingga hipotesis ketiga $\left(\mathrm{H}_{2}\right)$ diterima. Hal ini berarti semakin tinggi budget emphasis dalam penyusunan anggaran maka semakin tinggi senjangan anggaran, sebaliknya apabila semakin rendah budget emphasis maka semakin rendah senjangan anggaran yang terjadi pada OPD Kabupaten Badung.

Budget emphasis atau penekanan anggaran pada OPD Kabupaten Badung merupakan suatu tuntutan kinerja dalam mencapai target anggaran yaitu dengan cara menggunakan anggaran tersebut dengan efektif, karena anggaran tersebut berasal dari uang rakyat yang harus di pertanggungjawabkan demi kesejahteraan rakyat. Adanya tuntutan tersebut menyebabkan bawahan melakukan senjangan 
anggaran dengan melonggarkan anggaran saat tahap penyusunan anggaran, ini dilakukan karena bawahan ingin kinerjanya juga terlihat bagus dimata atasan serta demi tercapainya target anggaran yang telah ditetapkan sebelumnya. Hasil penelitian ini sejalan dengan hasil penelitian Wiguna dan Wirasedana (2016); Kusniawati dan Lahaya (2017); Yasa dkk., (2017); serta Aprila dan Hidayani (2012) yang menunjukkan bahwa budget emphasis berpengaruh positif pada senjangan anggaran.

Implikasi dari hasil penelitian ini mencakup dua hal, yaitu: 1) Implikasi teoritis dimana Hasil penelitian ini dapat memberikan tambahan informasi mengenai faktor yang mempengaruhi senjangan anggaran yang terdiri dari kejelasan sasaran anggaran dan budget emphasis.. Selain itu hasil penelitian ini mengkonfirmasi bahwa variabel budget emphasis dapat mempengaruhi terjadinya senjangan anggaran. Namun, variabel kejelasan sasaran anggaran yang tidak berpengaruh terhadap terjadinya senjangan anggaran, dikarenakan , anggaran pada anggaran sektor publik seringkali bersifat kaku dan susah disesuikan dengan keadaan yang sesungguhnya, para perancang anggaran dan pihak yang menggunakan dana anggaran harus mengikuti aturan mulai dari perencanaan, pengelolaan, realisasi, dan pelaporannya harus jelas sesuai dengan pedoman rencana kerja dan anggaran OPD Kabupaten Badung sehingga tidak ada penyelewengan dana yang dianggarkan dan tidak terjadi senjangan anggaran, baik itu senjangan lebih maupun senjangan kurang. Hasil penelitian ini membuktikan bahwa terdapat bukti empiris pengaruh kejelasan sasaran anggaran dan budget emphasis yang mempengaruhi senjangan anggaran. 2) Implikasi praktis dimana 
penelitian ini memberikan referensi masukan dan informasi bagi pihak yang terkait dalam penyusunan anggaran pada OPD Kabupaten Badung dalam pengambilan keputusan dan menentukan kebijakan di masa yang akan datang sekaligus meminimalisir senjangan anggaran, meningkatkan kinerja organisasi, serta menciptakan pemerintah yang transparan dan good governance.

\section{SIMPULAN DAN SARAN}

Berdasarkan hasil penelitian yang diperoleh melalui pengujian statistik, maka dapat ditarik dua kesimpulan: Kesimpulan pertama, kejelasan sasaran anggaran tidak berpengaruh terhadap senjangan anggaran pada OPD Kabupaten Badung. Dalam kondisi ini semakin tinggi maupun semakin rendah kejelasan sasaran anggaran dalam penyusunan anggaran tidak berpengaruh terhadap terjadinya senjangan anggaran pada OPD Kabupaten Badung. Hal ini karena dalam anggaran pada anggaran sektor publik seringkali bersifat kaku dan susah disesuikan dengan keadaan yang sesungguhnya, para perancang anggaran dan pihak yang menggunakan dana anggaran harus mengikuti aturan mulai dari perencanaan, pengelolaan, realisasi, dan pelaporannya harus jelas sesuai dengan pedoman rencana kerja dan anggaran OPD Kabupaten Badung sehingga tidak ada penyelewengan dana yang dianggarkan dan tidak terjadi senjangan anggaran, baik itu senjangan lebih maupun senjangan kurang. Kesimpulan kedua, budget emphasis berpengaruh positif terhadap senjangan anggaran pada Organisasi Perangkat Daerah Kabupaten Badung. Dalam kondisi ini variabel budget empahsis berpengaruh positif terhadap senjangan anggaran. Hal ini berarti 
semakin tinggi budget emphasis yang dilakukan oleh atasan kepada bawahan maka terjadinya senjangan anggaran akan meningkat.

Berdasarkan hasil penelitian dan simpulan di atas, maka saran yang dapat diberikan yakni Informasi yang dimiliki oleh pejabat yang terlibat dalam penyusunan anggaran agar dipergunakan untuk kepentingan organisasi bukan kepentingan pribadi, dapat mempertahankan atau bahkan harus meningkatkan transparansi dalam proses penyusunan anggarannya. dan dapat menciptakan pemerintahan yang good governance. Untuk peneliti selanjutnya diharapkan mengukur dengan menggunakan variabel lain dan menambahkan variabel moderasi yang berpengaruh terhadap senjangan anggaran

\section{REFERENSI}

Anthony, Robert N. dan Govindarajan. 2007. Management control system-12th ed. McGraw-Hill International Edition.

Aprila, Nila and Selvi Hidayani. 2012. The Effect Of Budgetary Participation, Asymmetry Information, Budget Emphasis And Comitment Organization To Budgetary Slack At SKPD Governmental Of Bengkulu City. Proceeding The 13th Malaysia Indonesia Conference on Economic, Management and Accounting (MIICEMA), 2 (2), pp.617-628.

Ardanari, I Gusti Agung Ayu Surya Cinitya dan I Nyoman Wijana Asmara Putra. 2014. Pengaruh Partisipasi Penganggaran, Asimetri Informasi,Self Esteem Dan Budget Emphasis Pada Budgetary Slack. E-Jurnal Akuntansi Universitas Udayana,7(3), hal.700-715.

Ayuni, Ni Made Kusuma dan Ni Made Adi Erawati. 2018. Pengaruh Asimetri Informasi Pada Senjangan Anggaran Dengan Kejelasan Sasaran Anggaran Dan Komitmen Organisasi Sebagai Pemoderasi. E-Jurnal Akuntansi Universitas Udayana, 22 (1), hal.492-520.

Biantara, Anak Agung Adi dan I. G. A. M. Asri Dwija Putri. 2014. Pengaruh Kejelasan Sasaran Anggaran, Etika, Dan Kepercayaan Diri Pada Senjangan Anggaran. E-Jurnal Akuntansi Universitas Udayana, 9 (2), hal.385-391. 
Daft, Richard L. 2014. Organziation Theory and Design. South-Western Cengage Learning, pp.1-649.

Douglas, Patricia Casey dan B. Wier. 2005. Cultural And Ethical Effects In Budgeting Systems: A Comparison Of U.S. And Chinese Managers. Journal of Business Ethics, 60 (2), pp.159-174.

Dunk, A. S. 1993. The Effect Of Budget Emphasis And Information Asymmetry On The Relation Between Budgetary Participation And Slack. The Accounting Review, 68 (2), pp.400-410.

Dunk, A. S. 1998. Antecedents Of Budgetary Slack: A Literature Review And Synthesis. Journal of Accounting Literature, 17, pp.72.

Erina, Ni Putu Dewik dan Wayan Suartana. 2016. Pengaruh Partisipasi Penganggaran, Penekanan Anggaran, Kepastian Individu, Dan Kejelasan Sasaran Anggaran Pada Senjangan Anggaran. Udayana, E-Jurnal Akuntansi Universitas, 15 (2), hal.973-1000.

Faria, Juliano Almeida de dan Sonia Maria Gomes da Silva. 2013. The Effects Of Information Asymmetry On Budget Slack: An Experimental Research. Academic Journal, 7 (13), pp.1086-1099.

Frucot, Veronique dan Winston T. Shearon. 1991. Budgetary Participation, Locus Of Control, And Mexican Managerial Performance And Job Satisfaction. Accounting Review, 66 (1) pp.80.

Ghozali, Imam. 2016. Aplikasi Analisis Multivariate dengan Program IBM dan SPSS 21. Semarang: Universitas Diponegoro.

Hansen, Dor R. dan Maryanne M. Mowen. 2006. Managment Accounting. Buku 1. Edisi 8. Jakarta: Erlangga.

Harvey, Mary Ellen. 2015. The Effect Of Employee Ethical Ideology On Organizational Budget Slack: An Empirical Examination And Practical Discussion. Journal of Business \& Economics Research,13 (1), pp.83-90.

Hariyanti, Tutik dan Oki Kuntaryanto. Pengaruh Partisipasi Anggaran Terhadap Senjangan Anggaran Dengan Aimetri Infformasi, Komitmen Organisasi dan Kejelasan Sasaran Anggaran Sebagai Variabel Moderating (Studi Pada Pemerintah Desa Di Kecamatan Jogonalan). Kiat BISNIS. 5(4).

Hobson, Jessen L., Mark J. Mellon, dan Douglas E. Stevens. 2011. Determinants Of Moral Judgments Regarding Budgetary Slack: An Experimental Examination Of Pay Scheme And Personal Values. Behavioral Research in Accounting, 23 (1), pp.87-107. 
Irfan, Muh, Budi Santoso, dan Lukman Effendi. 2016. Pengaruh Partisipasi Anggaran Terhadap Senjangan Anggaran Dengan Asimetri Informasi , Penekanan Anggaran Dan Komitmen Organisasional Sebagai Variabel Pemoderasi. Jurnal Akuntansi dan Investasi, 17 (2), hal.158-175.

Jensen, Michael C. dan William H. Meckling. 1976. Theory Of The Firm: Managerial Behavior, Agency Costs And Ownership Structure. Journal of Financial Economics, 3 (4), pp.305-360.

Karidwan Aji dan Amir Mahmud. 2014. Pengaruh Kejelasan Sasaran Anggaran Terhadap Senjangan Anggaran Dengan Asimetri Informasi Sebagai Variabel Moderasi. Accounting Analysis Journal.3(2)

Kenis, Izzettin. 1979. Effect On Budgetary Goal Characteristic On Managerial Attitudes And Performance. The Accounting Review, 4 (4), pp.707-721.

Kung, Fan-Hua, C-Huang dan C-Cheng. 2013. An Examination Of The Relationships Among Budget Emphasis, Budget Planning Models And Performance. Management Decision, 51 (1), pp.120-140.

Kusniawati, Heny dan Ibnu Abni Lahaya. 2017. Pengaruh Partisipasi Anggaran, Penekanan Anggaran, Asimetri Informasi Terhadap Budgetary Slack Pada SKPD Kota Samarinda. AKUNTABEL, 14 (2), hal.144-156.

Lu, Cheng-Tsung. 2011. Relationships Among Budgeting Control System, Budgetary Perceptions, And Performance: A Study Of Public Hospitals. African Journal of Business Management, 5 (1), pp.6261-6270.

Maiga, Adam S dan Fred A. Jacobs. 2008. The Moderating Effect Of Manager's Ethical Judgment On The Relationship Between Budget Participation And Budget Slack. Advances in Accounting, 23, pp.113-145.

Mardiasmo. 2018. Akuntansi Sektor Publik. Edisi Terbaru. Yogyakarta: ANDI.

Mukaromah, Aliati dan Dhini Suryandari. 2015. Pengaruh Partisipasi Anggaran, Asimetri Informasi, Komitmen Organisasi, Ambiguitas Peran Terhadap Budgetary Slack. Accounting Analysis Journal, 4 (4), hal.1-8.

Mulyadi. 2016. Sistem Akuntansi. Edisi 4. Jakarta: Salemba Empat.

Negara, Putu Ryan Sutha dan I Gde Ary Wirajaya. 2018. Pengaruh Partisipasi Penyusunan Anggaran Pada Budgetary Slack Dengan Komitmen Organisasi , Opportunistic Behavior Dan Ketidakpastian Lingkungan Sebagai Pemoderasi. E-Jurnal Akuntansi Universitas Udayana, 22 (3), hal.23392367.

Özera, Gokhan dan Emine Yilmaz. 2011. Effects Of Procedural Justice Perception, Budgetary Control Effectiveness And Ethical Work Climate On 
Propensity To Create Budgetary Slack. Business and Economics Research Journal, 2 (4), pp.1-18.

Pello, Elizabeth Vyninca. 2014. Pengaruh Asimetri Informasi Dan Locus Of Control Pada Hubungan Antara Penganggaran Partisipatif Dengan Senjangan Anggaran. E-Jurnal Akuntansi Universitas Udayana, 6 (2), pp.287-305.

Permana, Ody Tegar. 2017. Pengaruh Partisipasi Anggaran, Asimetri Informasi, Tekanan Anggaran Dan Komitmen Organisasi Terhadap Senjangan Anggaran Di Pemerintah Kabupaten Banyumas. Jurnal Organisasi dan Manajemen.

Pitasari, Kadek Krisna Aris, Ni Luh Gede Erni Sulindawati, dan Anantawikrama Tungga Atmadja. 2014. Pengaruh Kejelasan Sasaran Anggaran Dan Keadilan Prosedural Terhadap Sejangan Anggaran ( Budgetary Slack ) Pada SKPD Berupa Dinas Di Pemerintah Kabupaten Klungkung. E-Journal S1 Ak Universitas Pendidikan Ganesha, 2 (1).

Putri, Gusti Ayu Made Cika dan I G. A. M. Asri Dwija Putri. 2016. Pengaruh Kejelasan Sasaran Anggaran, Karakter Personal, Dan Information Asymmetry Pada Senjangan Anggaran. E-Jurnal Akuntansi Universitas Udayana, 14 (3), hal.1555-1583.

Raditya, Putu Ari dan I Gde Ary Wirajaya. 2018. Pengaruh Partisipasi Anggaran Dan Penekanan Anggaran Pada Senjangan Anggaran Dengan Locus Of Control Sebagai Variabel Pemoderasi. E-Jurnal Akuntansi Universitas Udayana, 22 (2), hal.1584-1599.

Robbins, Stephen P. 2015. Organizational Behavior . Edition $16^{\text {th }}$. Pearson.

Schiff, Michael dan Arke Y. Lewin. 1970. The Impact Of People On Budgets. The Accounting Review, 45 (2), pp.259-268.

Siegel, G. dan H. R. Marconi. 1989. Behavioral Accounting. South-Western Publishing Co. Ohio.

Simon, Mark, Susan M. Houghton dan K. Aquino. 2008. Cognitive Biases, Risk Perception, And Venture Formation: How Individuals Decide To Start Companies. Journal of Business Venturing, 15 (98), pp.113-134.

Sinaga, Mardongan Tua. 2013. Pengaruh Partisipasi Anggaran Terhadap Senjangan Anggaran Dengan Locus Of Control Dan Budaya Organisasi Sebagai Variabel Pemoderasi (Studi Empiris Pada SKPD Kota Pematang Siantar). Fakultas Ekonomi Universitas Negeri Padang.

Sugiyono. 2017. Metode Penelitian Bisnis. Bandung: Alfabeta. 
Tresnayani, Luh Gede Ardi dan Gayatri. 2016 Pengaruh Partisipasi Anggaran, Asimetri Informasi, Kapasitas Individu, Dan Kejelasan Sasaran Anggaran Terhadap Potensi Terjadinya Budgetary Slack. E-Jurnal Akuntansi Universitas Udayana. 16(2), hal. 1405-1432.

Waller, William S. 1988. Slack In Participative Budgeting: The Joint Effect Of A Truth-Inducing Pay Scheme And Risk Preferences. Accounting, Organizations and Society, 13 (1), pp.87-98.

Wiguna, I Wayan Adi dan I Wayan Pradnyantha Wirasedana. 2016. Komitmen Organisasi Dan Asimetri Informasi Sebagai Pemoderasi Pengaruh Kejelasan Sasaran Anggaran Pada Senjangan Anggaran. E-Jurnal Akuntansi Universitas Udayana, 16 (3), hal.2435-2456.

Yasa, I Gede Mustika, I Putu Gede Diatmika, dan Made Aristia Prayudi. 2017. Pengaruh Partisipasi Anggaran, Penekanan Anggaran, Kejelasan Sasaran Anggaran, Dan Self Esteem Terhadap Senjangan Anggaran Desa Di Kecamatan Kubutambahan. E-Journal S1 Ak Universitas Pendidikan Ganesha, 8 (2).

Yeyen AZ. 2013. Pengaruh Revisi Anggaran, Partisipasi Anggaran, Tingkat Kesulitan, serta Evaluasi dan Umpan Balik Terhadap Pencapaian Anggaran yang Efektif (Studi Empiris pada Satuan Kerja Perangkat Daerah Kota Payakumbuh). Artikel Fakultas Ekonomi Universitas Negeri Padang.

Young, S. M. 1985. Participative Budgeting: The Effects Of Risk Aversion And Asymmetric Information On Budgetary Slack. Journal of Accounting Research, 23 (2), pp.829-842. 